(C) 2014

Лопушняк В. І., кандидат сільськогосподарських наук

Львівський національний аграрний університет

\title{
БАЛАНС СІРКИ ЗА РІЗНИХ СИСТЕМ УДОБРЕННЯ КУЛЬТУР У ЗЕРНО-ПРОСАПНІЙ ПЛОДОЗМІННІЙ СІВОЗМІНІ ЗАХІДНОГО ЛІСОСТЕПУ УКРАЇНИ
}

\section{Рецензент - доктор сільськогосподарських наук, професор, академік АН ВО Украӥни 3. М. Томашівський}

\begin{abstract}
Зерно-просапні плодозмінні короткоротаційні сівозміни західного Лісостепу України відзначаються від'ємним балансом сірки. Органо-мінеральна система удобрення з внесенням $40 \mathrm{~m} / 2 а$ гною $+15 \mathrm{~m} / 2 a$ сидерату $+5 \mathrm{~m} / 2$ а соломи $+N_{50} P_{85} K_{113} i$ насиченістю сівозміни органічними добривами $(15,0 \mathrm{~m} / \mathrm{za})$ забезпечує додатний баланс сірки - близько 10 кг/га сівозмінної площңі. Найбільшим виносом сірки в зернопросапній плодозмінній сівозміні відзначаються буряк иукровий $і$ конюшина лучна, які з основною й побічною продукиією забезпечують близько 80 \% від загального виносу иього елемента всіма культурами.
\end{abstract}

Ключові слова: система удобрення, темносірий опідзолений трунт, сірка, баланс.

Постановка проблеми. У сучасних системах удобрення польових культур часто недооцінюється роль сірки як важливого елемента мінерального живлення. Через подібність зовнішніх ознак прояву голодування на азот нестачу сірки в агроценозах не завжди виявляють, що зумовлює необхідність додаткового вивчення балансу цього елемента в польових сівозмінах.

Аналіз останніх досліджень і публікацій, у яких започатковано розв'язання проблеми. Зростаючий інтерес до мінерального живлення сіркою зумовлений підвищенням загального рівня врожаю в агроценозах і підвщенням виносу цього елемента 3 грунту. Науковці вважають сірку «четвертим макроелементом» 3 огляду на її фізіологічну роль (яка подібна до азоту) і винос, що співрозмірний із виносом фосфору $[4 ; 7]$.

Низький вміст сірки може обмежувати ефективність дії мінеральних добрив, а за його дефіциту втрати врожаю коливаються в межах 15$40 \%[3 ; 6]$.

Основним джерелом сірки є грунт; iї запаси визначаються вмістом гумусу, поскільки близько $90 \%$ елемента в грунті міститься в органічних сполуках [1]. Він може бути доступним лише в процесі мінералізації та поглинання у вигляді сульфат-іону $\mathrm{SO}_{4}{ }^{2-}$, проте цей аніон у грунті $€$ лабільним і може інтенсивно мігрувати по профілю [5]. На бідних за гумусом грунтах рослини більше потерпають від нестачі сірки [1].

Дослідження балансу сірки в грунтах Лісостепу і Полісся показало стійку тенденцію до зменшення. Показники балансу сірки набули від'ємних значень через те, що все менше вноситься сірковмісних добрив. Промислове виробництво й надходження з повітря та 3 атмосферними опадами також зменшилося. У Лісостепу надходження елемента 3 мінеральними добривами коливається в межах 17,9-23,6, а 3 органічними - 3,0-4,3 кг/га [2]. Тому в умовах західного Лісостепу України, який відзначається достатнім (в окремі роки - й надмірним зволоженням), а також порівняно невисоким вмістом гумусу в грунтах, необхідно ретельно оцінювати стан мінерального живлення сіркою в системах удобрення польових культур і баланс цього елемента в агроценозах.

Метою наших досліджень було встановити закономірності балансу сірки в темно-сірому опідзоленому грунті західного Лісостепу України під впливом різних систем удобрення сільськогосподарських культур у польовій плодозмінній сівозміні.

Виходячи $з$ мети, завданням досліджень було визначити особливості динаміки вмісту рухомих форм сірки в грунті та вивчити статті балансу сірки в сівозміні під впливом різних систем удобрення.

Матеріали і методи досліджень. Польові дослідження проводили впродовж 2009-2012 рр. в умовах стаціонарного досліду в короткоротаційній польовій плодозмінній сівозміні кафедри грунтознавства, землеробства та агрохімії Львівського національного аграрного університету 3 таким чергуванням культур: пшениця озима, буряк цукровий, ячмінь ярий із підсівом конюшини, конюшина лучна.

Варіанти досліду:

1) без добрив (контроль);

2) мінеральна система удобрення $-\mathrm{N}_{390} \mathrm{P}_{210} \mathrm{~K}_{430}$;

3) органо-мінеральна система удобрення 20 т/га гною +5 т/га соломи $+\mathrm{N}_{270} \mathrm{P}_{153} \mathrm{~K}_{260}$, насиченість сівозміни органічними добривами $-6,25$ т/га; 


\section{СІЛЬСЬКЕ ГОСПОДАРСТВО. РОСЛИННИЦТВО}

4) органо-мінеральна система удобрення 30 т/га гною + 15 т/га сидерату + 5 т/га соломи + $\mathrm{N}_{100} \mathrm{P}_{110} \mathrm{~K}_{173}$; насиченість сівозміни органічними добривами - 12,5 т/га;

5) органо-мінеральна система удобрення 40 т/га гною + 15 т/га сидерату + 5 т/га соломи + $\mathrm{N}_{50} \mathrm{P}_{85} \mathrm{~K}_{113}$; насиченість сівозміни органічними добривами - 15,0 т/га;

6) органічна система удобрення - 50 т/га гною +15 т/га сидерату + 5 т/га соломи $+\mathrm{N}_{25} \mathrm{P}_{60} \mathrm{~K}_{50}$; насиченість сівозміни органічними добривами 17,5 т/га (для збалансування елементів мінерального живлення та поліпшення процесу мінералізації соломи додатково вносили $\mathrm{N}_{25} \mathrm{P}_{60} \mathrm{~K}_{53}$ ).

Із мінеральних добрив під зяблевий обробіток грунту вносили суперфосфат гранульований i калійну сіль змішану, аміачну селітру - під передпосівний обробіток і в підживлення.

Після попередніх розрахунків балансу сірки замість частини калійної солі вносили каліймагнезію, що містить сірку. В усіх варіантах (окрім контролю) норма цього добрива становила 50 кг/га за вмістом калію в діючій речовині, що, відповідно, забезпечувало внесення сірки 25 кг/га.

3 органічних добрив в основне удобрення під буряк цукровий використовували соломистий напівперепрілий гній великої рогатої худоби, редьку олійну на сидерат і солому пшениці озимої. Загальна площа дослідної ділянки -450 м², облікової - 374 м², повторність досліду - триразова, розміщення ділянок систематичне.

Аналізи грунтових і рослинних зразків проводили згідно з методиками, прийнятими в агрохімічних дослідженнях, зокрема визначали рухомі форми сірки за методом ЦІНАО згідно 3 ГОСТ 26490-85.

Результати досліджень. В умовах дослідного поля 3 опадами в грунт надходило близько 7,0 кг/га сірки, а 3 насінням у зерно-просапній сівозміні за нашими розрахунками надходить 0,3-0,4 кг/га сірки за рік. Із мінеральними добривами сірка вноситься переважно в складі суперфосфату і калімагнезії.

Вміст сірки у суперфосфаті становить близько $11 \%$, у напівперепрілому соломистому гної близько 0,05, у зеленій масі сидеральних культур - близько 0,3, а в соломі зернових культур - до $0,12 \%$ у перерахунку на суху речовину [5].

Надходження сірки зі сидератами, враховуючи їхній хімічний склад, і соломою досягало 15,8 кг/га. Значний вплив на надходження сірки в умовах досліду мав гній (див. табл.).

Розрахунки показують, що в умовах досліду надходження сірки за ротацію сівозміни було в межах 55-80 кг/га сівозмінної площі.

Витратна частина балансу залежала від продуктивності культур і коливалася в межах 5269 кг/га сірки, що сприяло від'ємному балансу сірки (44,9 кг/га сівозмінної площі) в контрольному варіанті.

Застосування мінеральних добрив суттєво знизило дефіцит сірки (на 38,3 кг/га), проте баланс залишався від'ємним - у межах 7 кг/га.

Сумісне застосування органічних і мінеральних добрив забезпечувало зниження дефіциту сірки та їі позитивний баланс до 6-10 кг/га сівозмінної площі.

Баланс сірки за різних систем удобрення культур у зерно-просапній плодозмінній сівозміні (середнс за 2009-2012 роки), ка/га

\begin{tabular}{|c|c|c|c|c|c|c|c|c|c|c|}
\hline \multirow[b]{3}{*}{ Варіант } & \multicolumn{4}{|c|}{ Надходження } & \multicolumn{5}{|c|}{ Винос (основна і побічна продукція) } & \multirow[b]{3}{*}{ 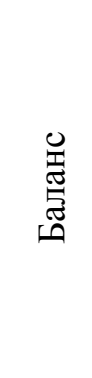 } \\
\hline & \multirow[b]{2}{*}{ 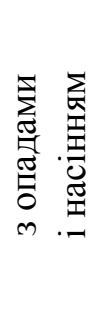 } & \multicolumn{2}{|c|}{3 добривами } & \multirow[b]{2}{*}{$\begin{array}{l}\Sigma \\
0 \\
\tilde{\Xi} \\
\stackrel{0}{0}\end{array}$} & \multirow[b]{2}{*}{ 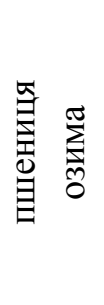 } & \multirow[b]{2}{*}{ 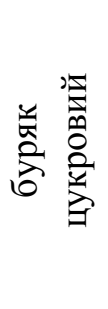 } & \multirow[b]{2}{*}{ 思瓷 } & \multirow[b]{2}{*}{ 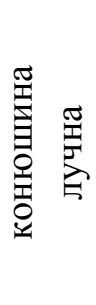 } & \multirow[b]{2}{*}{$\begin{array}{l}\Sigma \\
\tilde{0} \\
\tilde{\Xi} \\
\tilde{z}\end{array}$} & \\
\hline & & 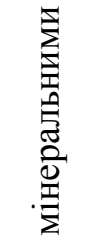 & 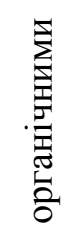 & & & & & & & \\
\hline 1 & 7,4 & 0 & 0 & 7,4 & 6,3 & 26,3 & 4,6 & 15,1 & 52,3 & $-44,9$ \\
\hline 2 & 7,4 & 48,1 & 0 & 55,5 & 8,8 & 30,7 & 5,3 & 17,3 & 62,1 & $-6,6$ \\
\hline 3 & 7,4 & 38,5 & 25,8 & 71,7 & 9,7 & 32,8 & 5,4 & 17,8 & 65,7 & 6,0 \\
\hline 4 & 7,4 & 37,1 & 30,8 & 75,3 & 10,4 & 33,6 & 5,7 & 18,1 & 67,8 & 7,5 \\
\hline 5 & 7,4 & 34,4 & 35,8 & 77,6 & 10,7 & 34,5 & 5,7 & 18,5 & 69,4 & 8,2 \\
\hline 6 & 7,4 & 31,3 & 40,8 & 79,5 & 10,6 & 34,2 & 5,9 & 18,4 & 69,1 & 10,4 \\
\hline
\end{tabular}




\section{СІЛЬСЬКЕ ГОСПОДАРСТВО. РОСЛИННИЦТВО}

Розрахунками також встановлена тісна залежність балансу сірки від вмісту їі рухомих форм у темно-сірому опідзоленому грунті.

За підвищення вмісту рухомої сірки у два рази - від 3,1 кг/га до 6,2 кг/га [5] - усувається дефіцит сірки в грунті й спостерігається їі додатний баланс у межах 6-10 кг/га.

Істотний кореляційний зв'язок цих показників підтверджується значенням множинного коефіцієнта детермінації $\left(R^{2}=0,66\right)$.

Висновки: 1. Органо-мінеральна система удобрення 3 внесенням 40 т/га гною +15 т/га сидерату +5 т/га соломи $+\mathrm{N}_{50} \mathrm{P}_{85} \mathrm{~K}_{113}$ i насиченістю сівозміни органічними добривами (15,0 т/га) забезпечує додатний баланс сірки за вирощування культур у польовій плодозмінній сівозміні. Враховуючи рівень врожайності основної та побіч-

\section{БІБЛІОГРАФІЯ}

1. Адаменко С. М. У вітчизняному землеробстві роль сірки поки що недооцінена / С. М. Адаменко, С. Г. Машинник // Агроном. - 2010. № $1 .-$ C. $38-43$.

2. Богданович Р. П. Значення та баланс сірки в грунті / Р. П. Богданович, А. М. Широконос // Агрохімія і грунтознавство : міжвід. темат. наук. зб. - Спец. вип. : Грунти - основа добробуту держави, турбота кожного. - Х., 2006. - Кн. 3. C. $8-10$.

3. Господаренко Г. М. Агрохімія : підручник / Г. М. Господаренко. - К. : IAE, 2010. - 400 с.

4. Лісовий М. В. Роль сірки у живленні рослин та застосування сірчаних добрив / М. В. Лісовий // Посібник українського хлібороба : наук.-вироб. ної продукції найвищим виносом сірки відзначаються буряк цукровий (близько 50 \% від загального виносу культурами) і конюшина лучна (20-30\%).

2. Незважаючи на високі показники виносу сірки 3 основною й побічною продукцією $(0,8-$ 1,2 кг/т), зернові з урожаєм виносять найменше цього елемента порівняно з іншими культурами сівозміни. Тому в системах удобрення на темносірих опідзолених грунтах, окрім органічних добрив, нетоварної частини врожаю і сидератів, слід передбачати застосування сірковмісних добрив, зокрема калімагнезії в нормі 20-30 кг/га за вмістом сірки в діючій речовині, застосування яких легко усуває негативний баланс цього елемента в зерно-просапних плодозмінних сівозмінах західного Лісостепу України.

щорічник. - К., 2010. - С. 164.

5. Лопушняк $B$. Динаміка рухомих форм сірки у темно-сірому опідзоленому грунті під впливом різних систем удобрення / В. Лопушняк // Вісник Львівського національного аграрного університету : агрономія. - 2013. - № 17 (1). - С. 154157.

6. Росановський О. Сірка як основний чинник високих і сталих врожаїв [Електронний ресурс] / O. Росановський. - Режим доступу : http://www2. agroscience.com.ua.

7. Хоменко О. Д. Сірчане живлення і продуктивність культурних рослин / О. Д. Хоменко // Вісник сільськогосподарської науки. - 1980. № 2. - С. 17-20. 